\title{
NUMSA and Solidarity's Responses to Technological Changes at the ArcelorMittal Vanderbijlpark Plant: Unions Caught on the Back Foot
}

\author{
Mondli Hlatshwayo, Centre for Education Rights, University of Johannesburg, \\ Johannesburg, South Africa
}

\begin{abstract}
Under the impact of globalisation and intensified international competition there has been an increased use of technology in the production processes in South African enterprises. No specific study of the impacts of technological changes on work and workers, and how trade unions have responded to technological changes at the workplace has been undertaken in post-apartheid South Africa. This article seeks to fill this void by examining trade union responses to technological changes at the ArcelorMittal Vanderbijlpark Plant. The responses of National Union of Metalworkers of South Africa (NUMSA; a predominantly black union) and Solidarity (a predominantly white union) to technological changes were generally reactive or on the back foot, with a general focus on wage bargaining by both trade unions.
\end{abstract}

\section{KEYWORDS}

Lean production, proactive responses, reactive response, technological changes, and trade union responses.

\section{Introduction}

The Iron and Steel Corporation of South Africa (Iscor) was privatised in 1989, and what followed was a series of changes towards a business strategy incorporating 'lean production' - a production method that emphasises producing according to customer specification and reducing waste. In addition, there was a separation of iron ore mining from iron and steel-making in 2002, accelerated increase of the use of technology, and finally the full global integration of the ArcelorMitall Vanderbijlpark Plant and the company when ArcelorMitall International took control of the plant and the company in 2006 (Hlatshwayo, 2012a; Mashilo, 2010). Over a period of just more than twenty years the steel plant in Vanderbijlpark changed from a state-owned plant that generally served the interests of the apartheid state and white workers, to a global plant that is 'deracialised' and serving the corporate interests of its new owners in Luxembourg.

The article does not seek to argue that all the changes in the plant and the company, ranging from the changing racial composition and skill to retrenchments, were solely caused by technological changes in the plant and the company. There were other factors which contributed to 
these drastic changes and these included work reorganisation and technological changes, democratisation in the country, increased global integration of the company and the plant, and the unbundling which separated Iscor's mining from iron and steel making in 2002 (Iscor, 2003; Hlatshwayo, 2012a). Some of these changes are discussed in the article to provide the reader with an overview of developments in the plant and the company since privatisation in 1989.

The central question of this article is: How did trade unions respond to technological changes at the Iscor/ArcelorMittal plant between 1989 - when the plant was privatised - and 2011? In answering this question, I will also establish that the South African literature on trade unions does not have a specific and detailed examination of trade union responses to technological changes, especially in a post-apartheid context. Therefore the sociological dimension of this research is that it is addressing the gap in the literature on the impact of technological changes on work and workers, and trade union responses to technological changes. The article examines trade union responses of two unions which come from a history of racial segregation: NUMSA (which is predominantly black) and Solidarity (predominantly white). In addition, these unions' membership historically occupied two different positions in the production process at the plant in Vanderbijlpark. NUMSA's base was largely semi-skilled and unskilled while Solidarity had a skilled membership. The salient point is that despite these different backgrounds, both unions adopted a reactive approach to technological changes. Put differently, the two unions 'tail-ended' management's work reorganisation and technological changes at the plant.

\section{Trade Union Responses to Technological Changes: Gaps in the Scholarship}

While the South African labour studies literature has, to a certain extent, examined trade union responses to work reorganisation or lean production, the area of trade union responses to technological changes as a specific research focus has not been examined in a scholarly fashion in the post-apartheid context, where the use of machinery and computer technology has led to very significant job losses (Jarvis et al., 1999). Therefore, this article intends to contribute by filling in the gap which exists in the South Africa labour studies literature.

I acknowledge the sterling contributions made by South African literature on workplace changes and technological changes and trade union responses during the apartheid era (Sitas, 1983; Webster, 1985). Based on Webster's (1985) work, it can be argued that one of the responses of white craft workers was to open up to non-artisans, and that this was meant to give the unions additional bargaining power. Until the 1960s, skilled white artisans controlled the metal industry through powerful craft unions (Forrest, 2005). By the mid-1960s however, white labour had struck a compromise with employers whereby it agreed to tolerate the upward mobility of black labour as machine operators in exchange for higher wages and the reservation of more skilled grades of employment for whites.

Unlike the 1960s where technology played an important role in the expansion of the workforce, in the 1980s lean production and the use of new technology began to play a role in reducing the workforce (Forrest, 2011). Forrest makes a link between technology and job losses: 'The introduction of new technology [my emphasis] and rationalisation cost thousands of unskilled workers their jobs. This accelerated during the 1980s' (Forrest, 2005: 84). 
In a paper written in the 1980s advising trade unions on how to respond to technological changes, Maree (1984) argued:

The introduction of new technology by private and public enterprises holds a potential risk for workers in that it may lead to reductions of the labor force even though it could on occasion involve an expansion or diversification of production resulting in increased employment (Maree, 1984: 1).

Maree (1984) advised trade unions to engage management around Technology Agreements. According to Maree (1984), these agreements should include consultation around new technology, information disclosure, saving jobs, expert advice, training and retraining, health and safety measures, sharing of technology benefits and the monitoring and evaluation of the impact of new technology on work and workers.

During the 2000s, several researchers conducted studies on work reorganisation and trade union responses in South Africa, examining in particular technological changes, plant layout, training and labour flexibility, and other principles of lean production such as supply chain management, customer-driven production and quality assurance (Jarvis et al., 1999; Phillips, 2000, Rosenthal, 2000a and 2000b; von Holdt, 2003, Masando, 2005, von Holdt and Webster, 2005; Maree \& Godfrey, 2005; Webster et al., 2009; Buhlungu, 2010; Mashilo, 2010). This scholarship helps deepen our understanding of the changing nature of work and the role of trade unions in a globally integrated South African economy.

As part of understanding trade union responses to work reorganisation, Mashilo (2010) and Masondo (2010) conducted research into 'lean production in the auto sector and trade union responses'. The conclusions of both authors are that unlike Industriegewerkschaft Metall (IG Metall), NUMSA was unable to respond proactively to work reorganisation that includes technological changes and lean production (Masondo, 2010; Mashilo, 2010).

However, unlike the afore-mentioned studies on labour relations, where the units of analysis were workplace changes and trade union responses to work reorganisation, low wages and poor working conditions, in this article I treat trade union responses to technological changes as the unit of analysis. By adopting this approach, particularly the workplace focus, I seek to make a contribution to South African sociological literature on the workplace, technological changes and trade unionism.

\section{International Examples of Trade Union Responses to Technological Changes}

Given that the South African literature has gaps concerning trade union responses to technological changes, one should examine the trends in the international literature. One does not want to impose other union responses to technological changes on NUMSA and Solidarity because conditions in each country are not the same. However, examining how trade unions in other countries have responded to technological issues may be thought-provoking for purposes of comparative analysis.

In the context of the restructuring of the steel industry in the United Kingdom (UK), Bacon et al. (1996: 26) argue that trade union responses to technological changes can be described as 'business as usual'. The authors further state: 'There is little evidence that the unions have been able 
to forge new methods of interest representation' (Bacon et al., 1996: 26). Elsewhere, Bamber (1988: 212) observes: '... American and British unions have traditionally placed more emphasis on bargaining after decisions have been made, rather than on participation in making decisions, in contrast to many of their German and Scandinavian counterparts...' Solidarity, NUMSA and trade unions in the UK, India, Nigeria and the United States seem to stick to traditional roles of trade unions such as focusing wage negotiations, with minimal involvement in production and technical changes at the workplace (Bacon et al., 1996; Lukman, 2007; Saiydan, 2002).

Ghosh et al., (2009) argue that the traditional role of trade unions has been to bargain with employers over wages and working conditions. Writing about the evolution of workers' struggles in Sweden, Sandberg (1985: 76) regards these issues (wages) as 'distribution' struggles of workers and trade unions. Sandberg (1985: 76) further argues that in the 1980s the role of Swedish trade unions evolved, and during the phase of lean production and technological changes trade unions in Sweden have been compelled to include 'production' issues such as technological changes and work reorganisation in their bargaining process. That shows that trade unions can move beyond their traditional roles and include production issues in their bargaining strategies.

Examining Australian unions' responses to technological changes and a shift to some proactive responses to technology, Mathews (1989: 163) advises: 'It is not enough to respond to employer's initiatives. ... Unions need to pursue an agenda of their own'. He provides, among other things, a case study of the railways in Victoria in Australia where management had introduced technological changes in the operations of the company in 1982. The Australian Minister of Transport made a proposal which included changes in technology and work reorganisation.

According to Mathews (1989: 164):

At this point the union representatives drew back, for fear of being overwhelmed by a process over which they had no control. ... Three job representatives (one each from the Australian railway Union, Amalgamated Metalworkers Union and the white collar Australian Transport Officers Association)were booked off, on paid leave, to do the necessary research in conjunction with their unions.

After consultations with their union membership, the union officials developed imaginative proposals which led to the following changes: - training and technological changes which saved jobs such as the setting up of a customer information centres (these actually created new jobs!), technological changes in switch boards which improved services to users, and improvements in the services of the ticket reservation centre. The plan worked because the unions were given space to conduct research and the state - the employer and the service provider - was willing to listen to the unions' proposals (Mathews; 1989).

In his specific examination of technological changes at the Australian Post Office in the 1990s, Mathews (1994: 211) argues:

There is now a widespread agreement that many of the widespread negative features, which have been associated with a transition to work with new technology, have had to do more with the authoritarian nature of its introduction than any of its intrinsic properties of computerisation. 
He then states that:

The Australian Post Office (in the early 1990s) seems to have learnt an important organisational lesson from the experience with the mechanised letter sorting initiatives that have come to grief in the past. The introduction of OCR (optical character recognition equipment), unlike its electro mechanical predecessor, is being managed on the basis of extensive consultation and agreement, at a national, state divisional and mail centre level (Mathew, 1994: 203-204).

The changes in new technology and workers and union participation by the Australian Postal and Communications Union led to an increase in efficiency and workers were also able to have a financial share of the gains.

Looking at the German experience, Thelen (1991) states that German unions like IG Metall initially took an apathetic attitude to technological changes in production, but the economic crisis of the 1970s compelled them to develop a proactive approach. The space to respond to technological change, as embodied in Works Councils and industry bargaining, came as a result of workers' struggles during the Second World War and tend to be regarded as part of an 'historic compromise' between labour, capital and the state which provides the German unions with some breathing space.

Reflecting on his involvement in work reorganisation with IG Metall and how the union introduced changes in technology in the late 1990s, Konrad Siegel, who worked in an agricultural equipment plant and was a former member of the works council at the plant in Germany, said:

Now the plant is one of the productive plants [in the industry] worldwide. ... As the works council, together with our members, we worked with existing technology and arranged it so that it led to an increase in productivity (Siegel, Konrad, Personal interview, 9 August 2012).

Unions that adopt a proactive approach to technological changes tend consistently to improve their internal capacity to engage by focusing on developing their research capacity and ensuring that production and technological changes are part of the union's agenda. In other words, they develop a delicate symmetrical relationship between wages and production issues, according to former IG Metall shop steward Konrad Siegel (Forrest, 2009).

In fact, both unions - NUMSA and Solidarity - tended to respond slowly and reactively to technological changes in the plant. This also has to do with the fact that union structures are generally insulated from production. Production issues only emerge as and when it starts affecting the positions of workers.

\section{Methodological Approach}

As an attempt at understanding how NUMSA and Solidarity responded to technological changes at the ArcelorMittal Vanderbijlpark Plant, I conducted research between 2009 and 2011. In the main, I used three difference sources of data, namely interviews, archival sources and factory visits. Firstly, this qualitative research I conducted is largely based on 87 in-depth interviews with members, shop stewards, leaders of Solidarity and NUMSA, retrenched workers, 2 ArcelorMittal 
managers and a member of the Metal and Engineering Industries Bargaining Council (MEIBC); archival sources; and a visit to the plant.

Secondly, I accessed the Iscor Library and Museum from July 2010 at the plant in Vanderbijlpark. The purpose of accessing documents from the library was two-fold. Firstly, I wanted to have a record of the nature and forms of technological change at ArcelorMittal from 1989 to 2011. Secondly, I also sought to establish reasons behind the introduction of these technological changes in the production process from a company perspective. Based on this motivation, I accessed annual reports, production plans and reports on plant activities. I also used NUMSA archives at the Wits Historical Papers in Johannesburg for purposes of understanding how NUMSA responded to technological changes at the plant. Given that Solidarity does not have an archive, I had to collect documents on Solidarity's responses to technological changes from its offices in Vanderbijlpark and Pretoria.

Finally, I visited the ArcelorMittal Vanderbiljpark Plant in June 2010. The purpose of the visit was to deepen my understanding of the production process and the role of technology in the plant (Hlatshwayo, 2010). The factory visit was not for the first time as I had visited the plant in 2003 (Hlatshwayo, 2003). The visit in 2010 started at the iron-making section, proceeded to the steel-making section and was concluded at the storage section of the plant. One of the observations I made was that the plant is capital intensive, with machine and computers playing a major role in the production process. There were very few workers. For example, at the steel coil-making section of the plant, which is about 600 meters, I only saw 5 workers working on the machines and most of the work was controlled by computers (Hlatshwayo, 2010).

All the above mentioned sources went through a process of triangulation which entailed comparing them and identifying consistencies and inconsistencies between interviews, archival and documentary sources and the factory visit (Neuman, 2010). All data sources indicated that there were technological changes at the plant and these contributed in part to the reduction of workers. There was also a general agreement that the two unions were unable to adequately respond to technological changes. Data analysis then took a thematic form with the aim of understanding trade union responses to technological changes (Zhang \& Wildemud, 2009), and that process led to common themes emerging, such as 'wages', 'research' and 'union education'.

\section{The Vanderbijlpark Steel Plant: A Site of Technological Changes}

The ArcelorMittal Vanderbijlpark Plant is a steel producing plant situated in the town of Vanderbijlpark, Gauteng Province, about $70 \mathrm{~km}$ south of the city of Johannesburg. The plant covers an area of approximately 0.8 square kilometres (ArcelorMittal, 2008). In 2012, the plant employed about 4500 people, almost $50 \%$ of ArcelorMittal SA's workforce. ArcelorMittal's head office in South Africa is located at the plant (Faku, 2013).

The plant's origins can be traced back to Iscor in Pretoria. Iscor, which became ArcelorMittal in 2007, was established as a state company in 1928, in terms of the Iron and Steel Industry Act. The objective of establishing the company was, first, to produce iron and a range of steel products from indigenous raw materials. Second, it was established as part of an attempt to create employment opportunities for white workers (Morris \& Kaplan, 1976; ArcelorMittal, 2008). As part of a process of furthering global integration of the company and restructuring, Iscor was privatised in 1989 (Hlatshwayo, 2003). 
The ArcelorMittal Vanderbijlpark plant (herein referred to as the plant), together with other plants and operations in Newcastle, Saldanha Bay, Vereeniging and Pretoria, constitute ArcelorMittal South Africa (SA) (ArcelorMittal, 2011). ArcelorMittal, a component of ArcelorMittal International, is the largest steel manufacturer on the African continent (ArcelorMittal, 2011). ArcelorMittal SA's global standing is further enhanced by being part of the world's largest steel producer, the ArcelorMittal International Group which employs 261,000 people on a global scale. ArcelorMittal International has a presence in 27 countries in Europe, the Americas, Asia and Africa (ArcelorMittal, 2011). In 2008, NUMSA and Solidarity had 2,464 and 2,406 members respectively at ArcelorMittal in South Africa (Agencies, 2008).

\section{From State-Owned Plant to a Global Plant of High Technology}

Technology featured prominently in the argument for the merger between Lakshmi Nivas Mittal Holdings (LNM) Group, a global player in the steel market, and Iscor, in 2004 (Competition Tribunal, 2004: 2). In 2006, the merger between Arcelor International and Mittal Steel International to create ArcelorMittal International further consolidated steel production at the global level. Once again, technology featured in this merger as a driving force. In 2006, ArcelorMittal argued: 'It [the partnership with ArcelorMittal International] will also assist us [ArcelorMittal SA] to provide the South African market with the latest in steel product technology' (ArcelorMittal, 2006: 20).

\section{Technological Change at the Vanderbijlpark Plant}

There is no doubt that technological changes and technological innovations were part of a company's strategy to remain in the steel market. In this section of the article I provide specific examples of the nature and form of technological changes that took place at the Vanderbijlpark Plant since 1989 when it was privatised. There were three types of technological changes in the plant, namely introduction of new machinery or constructing new sections in the plant, the upgrading of the existing machines, and the increased use of computer technology in the production process.

In 1990, there were alterations to the colour coating line at the Vanderbijlpark plant and this led to the acceleration of the production process in that section (Iscor, 1990). To meet the demands of the can and container market, a chrome plated steel line was commissioned at the plant in 1991. Electro galvanised sheets were produced in 1992 and these are used for making trucks, motor cars and building materials (Iscor, 1991 and 1992).

In 1991, the company reported a completion of 120,000 tons per year in the electrolytic chroming line at the plant. This was meant to boost the supply of materials for the can manufacturing industry. Relining and upgrading of blast furnace D in Vanderbijlpark was also reported, along with an upgrading of the hot-strip mill in the northern part of the plant. All these measures were aimed at increasing the productive capacity of the plant (Iscor South Africa, 1991).

There is a general agreement among trade unions, workers and management that there were technological changes at the plant (Hlatshwayo, 2012a). Piet Du Plooy who worked for the plant in the 1970s and left the plant in 2000s spoke about changes in technology at the plant since the 1990s: 
They [Iscor Vanderbijlpark Plant] were introducing new machines in the plants like the tin plant, for instance. This was the start of the new technology. This was automation. ... New machines and automation led to the reduction of personnel ( $\mathrm{Du}$ Plooy, Piet. 2010, interview).

Pheko Lucas Mofokeng, a former NUMSA shop steward at the plant, has been working at the plant in Vanderbijlpark since 1989, spoke specifically about the introduction of new technology at the plant, 'The remote controls of cranes were installed in 1996' (Mofokeng, 2011, interview).

Changes were not just in the form of the introduction of new machines and the building of new production sections in the plant, there was also an increase in the use of computer technology in Vanderbijlpark Plant. According to ArcelorMittal Communication Consultant Hendie Grobbelaar, production in the plant is based on order specifications from customers. Orders from customers are captured in a computer system which then enables the plant to organise raw materials and set in motion the production process (Grobbelaar, Hendie. Personal interview, 13 July 2010). The whole production system is computerised, enabling the plant to measure productivity and quality of products (Hlatshwayo, 2010).

\section{The Impact of Technological Changes and Work Reorganisation on Workers and Work}

Technological changes, work reorganisation, unbundling of steel and mining in 2002, increased globalisation and democratisation transformed ArcelorMittal South Africa (SA) from plants that employed largely unskilled, semi-skilled black workers and skilled white workers to a much smaller black and white permanent workforce which is largely semi-skilled and skilled. The changes at the plant and the company impacted at five levels, namely racial demographics of the company, skills, drastic reduction of the number of workers, changes in work and the decline of union influence.

The first level of change had to do with the fact that Iscor was an apartheid state corporation created in part to provide employment for whites; it employed an exceptionally high proportion of white workers. In 1996, the overwhelming majority of management positions at the Iscor Vanderbijlpark Plant were occupied by whites. Nearly $90 \%$ of skilled jobs were held by white workers while unskilled work was done almost exclusively by black workers, according to Rosenthal (2000b).

The plant reduced the size of the workforce in three ways. First, it offered white workers between the ages of 50 and 63 years early retirement in 1992, granting retrenchment packages, with the aim of encouraging conservative elements - who could not tolerate a democratic dispensation led by blacks and changes in the plant - to leave the company (Rosenthal, 2000b). Positions occupied by white workers were also affected by workforce reduction. Black migrant workers were managed by a large layer of white hostel managers, training managers and human resource managers. There was also a need to rationalise and bring together various departments that were racially divided because the 'new South Africa' was also about 'deracialisation' (Galeni, Osborn. Personal interview, 20 December, 2009). Later, in the mid-1990s, retrenchment packages were offered to black workers - mainly those with less formal education. Finally, additional 
workforce reductions were accomplished through subcontracting and outsourcing (Johnston, 2010).

In 2010, the company had a woman as Chief Executive Officer. Although there have been some demographic changes with blacks and black women occupying senior and top management positions, 60 percent of top positions are occupied by white males ${ }^{1}$ (ArcelorMittal, 2010). Therefore over a period of twenty years the company and the plant were transformed from a plant that employed white males in key and strategic positions to the one that incorporated blacks and black women in leadership and skilled positions. ${ }^{2}$

The second level of the impact of changes had to do with the reconfiguration of skills. Out of 9,233 employees, there were only 353 unskilled workers in $2010^{3}$. In other words, 93\% of the workforce is either skilled or semi-skilled (ArcelorMittal, 2010). This means that the company has achieved its goal of reducing the number of unskilled workers and having a smaller permanent workforce. This change had to do with the fact that new machines require workers who are computer literate. Workers who had less formal education were regarded by the company as not skilled and they were retrenched in the mid 1990s and early 2000s (Rosenthal, 2000a). The company also relies on outsourced workers who are employed by labour brokers. In 2010, outsourced workers comprised $40 \%$ of the workforce at the plant (Johnston, 2010).

The third level of change is the drastic reduction of the number of workers in the company, ${ }^{4}$ increase in expenditure on machinery and increase in revenue over a period of more than twenty years.

Chart 1: Employees, revenue and machinery

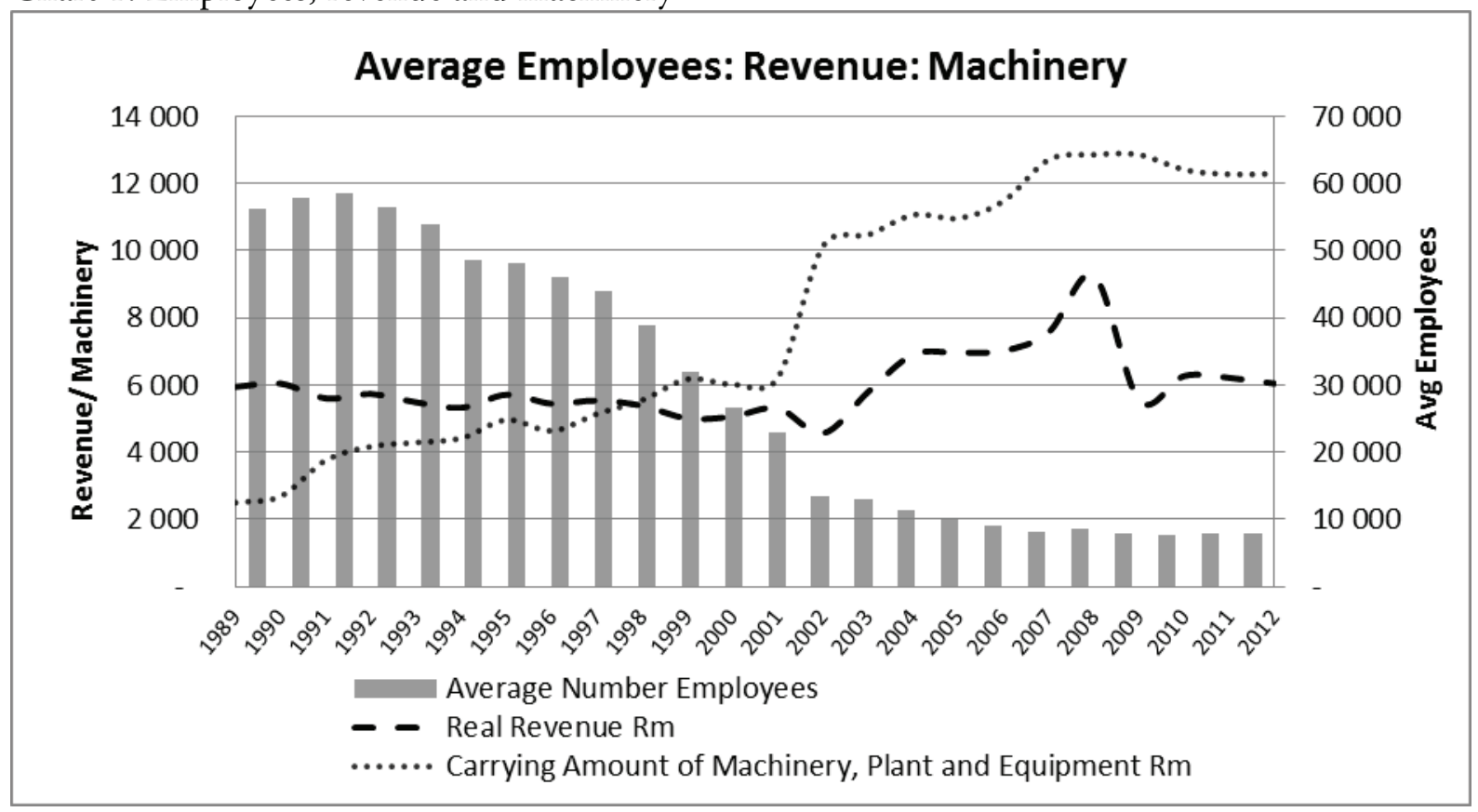

Source: Iscor and ArcelorMittal ${ }^{5}$

Revenue generated by the company's operations has increased from R 5,950m in 1989 to R $32,291 \mathrm{~m}$ in 2012 on a nominal basis - increasing by a multiple of 5.5 times, closely mirroring the escalation in the value of machinery, plant and equipment employed by the company. On a real 
basis, excluding the effects of inflation, revenue has increased from $R 5,950 \mathrm{~m}$ to $\mathrm{R} 6,043 \mathrm{~m}$ at a real average growth rate of $1 \%$.

A strong positive correlation of 0.96 (real: 0.53) was found to exist between the value of machinery, plant and equipment and revenue - emphasising the entity's reliance on capital assets. In contrast, a strong negative correlation of -0.88 (real: -0.43 ) exists between employee numbers and revenue earned, suggesting these two variables largely have a negative relationship. As revenue and machinery increases, the number of workers has been declining drastically. In 1989 there were 56,220 employees and the number was reduced to 7,900 in 2012.

Fourthly, William Dikotsi, a former chairperson of NUMSA's shop steward committee at the plant, argued that the reduction of the workforce tended to compel the remaining workers to work harder because machines and the production schedules usually speeds up the pace of work. He complained: 'We now have to work harder' (Dikotsi, William. Personal interview, 28 November 2010).

Finally, John Rodriguez, a chairperson of the Solidarity shop steward committee at the plant and a fitter and turner at the machine shop, admitted that retrenchments as a result of restructuring and the introduction of new machines and computers affected not only the workers but also the unions. He reflected:

At the time (in 1980s and 1990s) we were about 22,000 strong workers [at the Vanderbijlpark Plant] on the side and now we are only 5,000 including those who are working on contracts. (Rodriguez, John. Personal interview, 15 November 2010).

According to Xaba (2003: 42):

Employment figures at Steelco's [Iscor] Vanderbijlpark plant was 24,000 in 1984... And dropped to 14,000 in 1990 , and to 8,500 in 1998, when Steelco begun its restructuring process. It should be noted that the above figures cannot be verified as Steelco's [Iscor] management did not wish to release the official retrenchment figures.

Based on the above mentioned figures the plant in Vanderbijlpark lost close to 10,000 jobs since 1990. According to Faku (2013), there were 4,500 employees at the plant in 2012.

Having been weakened by the restructuring of work, how did trade unions at the plant respond to technological changes? Responses tended to be reactive in the sense that management in the plant used its power and control of the plant to initiate and implement technological changes, with the unions only objecting afterwards.

\section{Limited Consultation and Participation}

There are four participation fora that were introduced in the late 1980s and the 1990s and these were Omega, the Vanderbijlpark Project, an overseas trip and the OPEX-Challenge at the Vanderbijlpark Plant. Omega, a workplace restructuring programme based on quality circles, waste reduction, problem-solving, teamwork and worker participation was another manifestation of lean production. This programme was also about technological innovations in the production process. The Omega manual mentioned that machinery and materials were critical in improving 
productivity. Omega also discussed issues related to the identification of problems in the machinery and devising strategies for tackling them. It also emphasised productivity and the need to ensure that the plant became globally competitive (Iscor Vanderbijlpark, 1983).

Pheko Lucas Mofokeng spoke specifically about how the introduction of new technology and the lack of consultation led to the displacement of workers in his department.

... workers would be reduced from teams of 5 workers to teams of 2 workers. There was money for workers who participated in Omega and its training programmes. During this time Iscor Vanderbijlpark was also introducing new technology (Mofokeng, 2011, interview).

Omega had been introduced in 1983 among white workers and thus it did not cause divisions with the MWU (the predecessor of Solidarity), and this had to do with the fact that there were no immediate threats to these workers' position at the workplace (Hlatshwayo, 2012a).

The introduction of Omega at Iscor Vanderbijlpark led to deep divisions in the union. This led to violence and the killing of workers and their leaders (Zikalala, 1992). About 10 union members and leaders died (Forrest, 2005). Major issues were the 'Top 20' (20 workers who were elected as leaders by workers during a campaign against Omega) conflict, and the divisions between the shop stewards from the township and the migrants in the hostels (Hlatshwayo, 2003). At the heart of these divisions was the fact that a section of workers felt that shop stewards were no longer guided by the established principle of 'worker control' that NUMSA espoused (Hlatshwayo, 2003: 110).

All these contestations related to Omega weakened NUMSA because it had to focus on intraunion battles at the expense of workers' issues at the workplace. In that case, management benefits from a divided workforce because a united workforce is an obstacle to the implementation of managerial programmes which threaten the interests of workers. While workers engaged in intraunion rivalry, management was able to increase the rent at the KwaMasiza Flats where workers lived (Zikalala, 1992). The implications of Omega and the subsequent intra-union battles meant that NUMSA responded to technological changes as a weakened union.

In 1993, NUMSA, MWU and other unions at the plant also participated in the Vanderbijlpark Project which was a management and union forum. The forum was established in the early 1990s with the view to find 'solutions' to economic and production challenges at the plant. One of the founding principles of the project and the forum was the importance of workers in resolving production problems at the plant. According to the Vanderbijlpark Project, changes in technology necessitated some reorganisation of the workforce. The training of workers was also linked to technological changes at the plant. This is what the minutes say about this link:

In addition, production staff should have knowledge and insight in the machines and equipment (my emphasis) they operate in order not to damage them and to be able to function as highly aligned team together with other role players involved (Iscor Vanderbijlpark, 1993: 22).

The participation in the working group happened in a context of massive retrenchments and introduction of new technology. Participation in the restructuring forum seems to have been a rear guard action on the part of the union as management had already determined the agenda and pace of restructuring and the introduction of new technology. 
According to William Dikotsi, NUMSA stopped participating in the Vanderbijlpark Project during the phase of massive retrenchments in the late 1990s. The unions saw the project as a tool for managerial restructuring and technological changes which displaced workers. He stated, 'It became impossible to participate because we were losing members' (Dikotsi, 2012, telephonic interview).

Beyond the struggles around Omega and participation in the Vanderbijlpark Project, the union continued to grapple with technological changes. I asked Osborn Galeni, a former NUMSA organiser at Iscor, how the union responded to technological changes at the plant in 1996. According to Galeni, among other things, Iscor Vanderbijlpark organised study tours for the unions in the late early 1990s. '...Because the point was to make the union understand technological changes and workplace restructuring, management organised a visit to European steel plants. ... The IMF [International Metalworkers' Federation] was also involved. It raised issues and dangers in implementing this system' (Galeni, 2009: interview; Galeni cited in Xaba 2003: 73).

During that process NUMSA also used the visits as an opportunity for engaging sister unions who are also part of the IMF. The advice from these other unions was that the reorganisation of work and the introduction of new technology could lead to retrenchments, work intensity and longer working hours. These were seen as 'dangers', according to Galeni (2009, interview).

Xaba (2005) also confirms that both NUMSA and other unions in the plant were part of the 1996 delegation to England, Sweden and Germany, to observe the best international practices on steel production and training (Galeni, cited in Xaba, 2003: 73). One of Xaba's (2003) sources stated that the NUMSA delegates were mandated to acquire information on best practices before agreeing with any form of restructuring. According to the source:

But on their return the shop stewards agreed that management should restructure. Eventually, some shop stewards were promoted to higher positions, (Sansui cited in Xaba 2003: 73).

It however appears as if the trip to the overseas steel plant happened when management had already made up its mind about the nature and form of restructuring. Omega had been introduced among black workers way back in 1989 and already had elements of workplace restructuring and technological changes.

The overseas trips had predetermined outcomes from management's point of view. Iscor South Africa wanted NUMSA to understand the challenge of global competition and the 'necessity' to restructure the plant in Vanderbijlpark and introduce new technology. This teleological approach of management limits union participation in the sense that the outcomes of the visit were predetermined by management.

In analysing technological changes in the labour process both unions strongly argued that there was a lack of consultation in the process and they saw technological change as an imposition from management. Piet du Plooy, former MWU and Solidarity organiser, commented, 'Well, in those days [the 1980s and the early 1990s] they never consulted the unions' (Du Plooy, Piet. Personal interview, 1 August 2010).

Although trade unions raised general concerns about consultations, they also participated in the number of fora with the view to influence technological changes and work reorganisation. However, the feeling among the leadership of both trade unions was that consultation was not genuine in the sense that management had already taken decisions about new technology and 
restructuring, and the role of these fora was to rubber stamp such decisions (Du Plooy, Piet. Personal interview, 1 August 2010; Galeni, Osborn. Personal interview, 20 December 2009).

In the early 2000s, Solidarity and NUMSA had participated in the OPEX-Challenge and according to Solidarity representatives this programme which sought to train and place retrenched workers in workplaces was a complete failure. Perhaps du Plooy, who was intimately involved in the union as an organiser, summed up the experience best when he stated, ' $\mathrm{I}$ think it was all a complete fuss' (Du Plooy, Piet. Personal interview, 1 August 2010). Trade unions felt that the entire process led to retrenchments of their members and very few workers managed to get jobs outside the plant after retrenchment (Xaba, 2003).

\section{A Focus on Wages at the Expense of Technology and Work Reorganisation}

Dinga Sikwebu, NUMSA's national education officer, also reflects on the work of the union. He says, 'If you take the bulk of union work, it is around negotiations, bargaining on wages and all that' (Sikwebu, cited in Bramble \& Barchiesi, 2003: 206).

Both trade unions' bargaining strategies tended to put an emphasis on wages at the expense of technology and work reorganisation (Joubert, Paul. Personal interview, 1 September 2010; Ndebele, Bafana. Personal interview, 26 January 2011). The trade union emphasis on wages at the expense of technological changes was also noted by Velaphi Mjiyakho who facilitates negotiations between ArcelorMitall SA and the unions at the MEIBC. While the union has noted technological changes and work reorganisation as issues that affected work and workers, there has not been a serious engagement with these issues. Mjiyakho said: 'Unions do not want production and technology to meddle in wage negotiations. The key issue becomes wage increment. Technology and work reorganisation are discussed at the plant level' (Mjiyakho, Velaphi. Personal interview, 11 February 2011).

I noted that as 'As at end of November, The Council represented approximately 10,624 firms and 306,747 employees in the industry' (MEIBC, 2013: 1). However, it has to be understood that NUMSA, Solidarity and ArcelorMittal SA have a special bargaining arrangement at the MEIBC, and this arrangement dates back to the 1980s and is called a 'house' agreements arrangement. Mjiyakho also said, 'I facilitate the very specific collective bargaining negotiations between ArcelorMittal and Solidarity and NUMSA' (Mjiyakho, Velaphi. Personal interview, 11 February 2011). While specific technology bargaining take place at the plant level, NUMSA and Solidarity could have used this special arrangement in the bargaining council to negotiate technological changes with the employer. For example, in addition to plant level bargaining, IG Metall uses bargaining councils to develop an industry-wide approach to technological changes (Mashilo, 2010).

Union resources, work and structures tend to focus on wages. Even the union collective actions like strikes tend to be geared towards putting pressure on management largely during wage negotiations (Lourens, 2004; Mthiyane, 2008). On one level this is understandable, since workers rely upon their wages to purchase goods and services necessary to sustain themselves and their families. However, this is a one-dimensional strategy which also focuses on distribution of value created in the plant implicitly, and it grants management essentially uncontested power to change production to suit the interests of owners. 
The wage struggle also has an historical element in the case of NUMSA. Under apartheid, unions fought against the apartheid wage gap and the fact that black workers lived under far worse working conditions than their white counterparts. In 1995, NUMSA adopted a strategy called, 'NUMSA's Three-year Programme: Closing the Apartheid Wage Gap'. This was seen as part of 'strategic unionism' by the union leadership because it was viewed as being proactive and addressing the legacy of the 'apartheid wage gap' (von Holdt, 1995: 13-14).

Solidarity officials were asked why the union tended to focus on wages at the expense of technology and other production issues. The union's response was that 'the members determine issues and demands for collective bargaining' (Hlatshwayo, 2012b: 1).

Trade union officials and shop stewards have a responsibility of putting technology and production issues on the membership agenda because, as it has been shown in this article, workplace changes and technological changes play a role in changing the nature of work and retrenchments which, of course, weaken the union and workers. Union leadership is supposed to be dialogical in the sense that union members learn from union officials and leaders and vice versa (Freire, 1993).

\section{'Palace Politics' and 'Politics of the Past'}

In addition to a wage focus, NUMSA, as part of the Congress of South African Trade Unions (COSATU) and the African National Congress (ANC) alliance, tends to view alliance politics as one of the key centres of its activities. Engagement in the politics of 'upward social mobility' as articulated by Masondo (2012) is tied to the fact that the ANC, as a political party leading the South African government, provides opportunities of 'upward social mobility' for union leaders and shop stewards. This 'upward social mobility' also expresses itself at the plant. Some former shop stewards at the plant, like Pheko Mofokeng, have become ANC councillors in local government (Mofokeng, Pheko. Personal interview, 20 February 2011). Some shop stewards have also been promoted into positions as human resource managers or other management positions. This has weakened the union on the shop floor according to Alex Mashilo, co-ordinator of collective bargaining at the union head office (Mashilo, Alex. Personal interview, 3 June 2011).

COSATU's report to the 11th National Congress of the union held in 2012 reflected on COSATU's emphasis on 'palace politics' or what I call 'politics from above'. The report argued: 'However there is a case to be made for the argument that too much of the Federation's energy and time is being absorbed in politics, and particularly in "palace politics"' (COSATU, 2012: 98). COSATU expanded this point, saying, 'Anyone doubting that this imbalance exists needs to examine the relative time, energy and resources our structures spend on political issues' (COSATU, 2012: 98).

This implies that the federation and, by extension, its affiliates such as NUMSA admit that 'palace politics', which focuses on internal ANC power battles, takes place at the expense of concrete 'politics from below', which entails building union structures on the shop floor, engaging work reorganisation and technology, and the strengthening of labour by conducting factory-based research and education on technology. The focus on wages and politics of 'upward social mobility' has been at the expense of addressing issues of production and technological changes. This may explain why the union has not been able to respond proactively to such changes. In other words, 
most of the time and resources of NUMSA and other COSATU unions are spent on wages and alliance politics.

On the other hand, Solidarity's history is tainted with racism and segregation, or the 'politics of the past'. In the days of African Mine Workers Union (AMWU) and the 1922 white miners' strike, the union defended the rights of white workers. The union was a product of the sociopolitical system of apartheid. This is 'reflected in the predominantly white and Afrikaner membership of Solidarity' (Mantashe, 2008: 25). Solidarity's constitution has been amended to include black workers as members. Themba Makhathini is one of the black members belonging to Solidarity at the plant (Makhathini, Themba. Personal interview, 25 January 2010).

Solidarity 'outsourced' its politics to the Afriforum because it wanted to focus on building its structures, innovation in organising workers which included having a call centre for solving members' work related problems, a radio station and servicing of its membership (Mantashe, 2008; Visser, 2006; Dykema. Personal interview, 25 January 2010). While this strategy could be commendable from a union servicing point of view, it did not include developing a response to technological changes at the Vanderbijlpark Plant.

In the late 2000s, Solidarity formed Afriforum, which largely speaks on behalf of 'Afrikaners' and whites in South Africa, indicating that the union has not made a complete break with its past (Diamond, 2010). At the same time, it must be noted that the union has at times collaborated with predominantly black unions in post-apartheid South Africa. For example, Solidarity worked with COSATU's Communication Workers' Union (CWU) in exposing the greed of Telkom's top management, which amounted to pocketing profits of the company at the expense of workers (Solidarity, 2006). According to Osborn Galeni, a former NUMSA national organiser who was responsible for servicing NUMSA members at the plant, 'There has also been collaboration between the two unions at the plant, especially during the retrenchments in the 1990s' (Galeni, Osborn. Personal interview, 20 December 2009).

Despite these occasional instances of collaboration with predominantly black unions, the positions taken by Solidarity and Afriforum seem nevertheless to have helped perpetuate the institutionalised legacy of racism that colonisation and Apartheid entrenched. By opposing affirmative action without suggesting alternative ways of dealing with the fact that white workers benefited from Apartheid in society and the workplace, Solidarity has hardly contributed toward making a break with the apartheid 'past'. At the same time, these organisations have not addressed questions pertaining to technological changes - the impacts of which have disproportionately affected black workers.

\section{Research and Education}

Research and education has been used by both trade unions as tools for building internal capacity but these initiatives have not focused on production and technological changes. Research in Solidarity tends to focus on wages, as part of preparing the union for wage bargaining with employers. Joubert, the head of research at Solidarity, was asked if the union conducts research on the role of technology in work processes. His response was: 'Well, it [the research] is not directly [on technological changes] but most of the time it does come in as an incidental factor.... We have not looked at it as a subject specifically' (Joubert, Paul. Personal interview, 1 September 2010). 
Unlike Solidarity, NUMSA has at least tried to engage 'production' research. While NUMSA has generally focused on wages as part of its collective bargaining, in 2009 and 2010 it conducted ground-breaking research into the automobile sector. Combined with the fact that NUMSA has enjoyed support from outside organisations and researchers who are trying to help the union in dealing with production matters since 2009 , it is relatively advanced in this regard compared to Solidarity (Mashilo, 2010; Masondo, 2010; Webster et al., 2009).

Regarding union education, Solidarity's emphasis tends to be on basic union issues such as 'handling of labour cases and wage negotiations' (Dykema, Reint: Personal interview, 22 February 2011). By contrast, NUMSA has a broad education programme which includes shop steward training on labour laws, as a well as a political economy education programme. At least in the South African context, NUMSA may perhaps be regarded as having quite an intensive education programme. The limitation of NUMSA's education programme is that it has not examined in detail the question of production and technology. Possibly that has to do with NUMSA's general focus on wages and broader political issues (NUMSA, 2012).

NUMSA used the research on work reorganisation in the automobile industry sector to educate its shop stewards in the industry about work reorganisation. However, education on the work reorganisation research has only been conducted among shop stewards of the automobile industry. There has been no education on technological changes and production at ArcelorMittal Vanderbijlpark Plant. (Mashilo, Alex. Personal interview, 3 June 2011). The critical issue here is that union organisers and shop stewards are not trained and educated in handling production and technological questions.

\section{Lessons from NUMSA's Automobile Research}

Writing about trade union responses to work reorganisation in Germany and South Africa in the automobile industry with the view to advise NUMSA on how it should generally respond to technological changes and work reorganisation, Webster et al. (2009:78) state that: 'The Works Council [in Germany] has an Information and Technology Committee which monitors the use of all information that the company obtains about workers, including information obtained through cameras that record all movements and that are installed throughout the premises of most companies'.

NUMSA at ArcelorMittal SA and the plant can learn from the studies conducted by Masondo (2010), Mashilo (2010) and Webster et al (2009) because these studies put an emphasis on developing a proactive approach to changes in production by conducting research seeking to deepen an understanding of production processes, establish union departments dealing with production issues, training union structures and membership participation so that they can negotiate change, minimising the negative impact of technological changes and production on workers. This type of engagement does not exclude unions using strikes and negotiations to advance interests. This approach is regarded as a 'strategic' one in responding to production (Webster et al., 2009; Mashilo, 2010). The research conducted by Webster et al. (2009) makes a very important and a general recommendation which has been implemented by NUMSA. It argues that the union should revive the Research and Development Groups whose role, among other things, is to conduct research on workplace changes and productions issues on the shop floor. 


\section{Conclusion}

Despite a generalised control of factories by management, unions in Germany, Australia and Sweden have responded by combining traditional union campaigns for wages and working conditions with interventions in the sphere of production and technologies. A dual strategy which combines both traditional union issues and production may help in saving some jobs. A development of a proactive approach has to do with the unions realising that it is not just about collective bargaining over wages and working conditions, it is also about bargaining over production issues which play a role in the very existence of workers at the workplace. In other words, the role of trade union is evolving and unions like NUMSA and Solidarity are beginning to realise that bargaining has to include technology and other production related issues. In fact, even unions like IG Metal developed a proactive approach after realising that a wage focus as a strategy has limitations. A reactive approach is not just about a North-South divide because even the unions in the UK and America are regarded as being reactive when it comes to technological changes (Bamber, 1983).

\section{INTERVIEWS}

Dikotsi, W. (2010) Personal interview, 28 November.

Dikotsi, W. (2012) Telephonic interview, 20 September.

Du Plooy, P. (2010) Personal interview, 1 August.

Dykema, R. (2011) Personal interview, 22 February.

Galeni, O. (2009) Personal interview, 20 December.

Grobbelaar, H. (2010) Personal interview, 13 July.

Joubert, P. (2010) Personal interview, 1 September.

Makhathini, T. (2011). Personal interview, 25 January.

Mashilo, A. (2011) Personal interview, 3 June.

Mjiyakho, V. (2011) Personal interview, 11 February.

Mofokeng, L.P. (2011) Personal interview, 20 February.

Ndebele, B. (2011) Personal interview, 26 January. 
Rodriguez, J. (2010) Personal interview, 5 November.

Siegel, K. (2012) Personal interview, 9 August.

\section{NOTES}

1. The company did not provide figures on the demographic breakdowns at the plant in Vanderbijlpark.

2. The company did not provide figures on racial breakdown in the 1989 and the 1980s. However it is well known that top positions in the company were occupied by white males (Hlatshwayo, 2003).

3. Although the company did not avail figures on the skills composition in the 1980s and the 1990 s and there are no breakdown of figures per plant owned by the company, it is generally accepted by scholars that Iscor largely had a huge layer of the so called semi-skilled and unskilled workers and black workers were part of this skills category (Xaba, 2003; Morris and Kaplan, 1976).

4. The company does not provide a breakdown of employment levels according to each plant. Other scholars who have also studied the plant were also unable to access this information (see Xaba, 2003; Hlatshwayo, 2003). As stated, the Vanderbijlpark Plants has always had bigger propositions of workers (more than 50 per cent of the workforce) as it is one of the biggest steel plant in the southern hemisphere, and it is the biggest ArcelorMittal plant on the African continent and South Africa (ArcelorMittal, 2011). The company is not keen on sharing information with the public and the researcher. I had to go to the High Court in Pretoria and the Supreme Court of Appeal in Bloemfontein as part of my struggle for access to information. Among other things, the company argued that many records were destroyed (See the court judgment by Conradie, 2006).

5. This table was constructed with the assistance of Shaun Croock (2013), an Accounting Clerk also specialising in financial analysis of company reports at the University of Johannesburg. The data was sourced from Iscor and ArcelorMittal annual reports.

\section{REFERENCES}

Agencies (2008) 'ArcelorMittal South Africa agrees 12pc pay increase'. Economic Times. 19 May 2009 [Online]. Available at http://articles.economictimes.indiatimes.com/2008-05-19/news/ 27714429_1_steelmaker-arcelormittal-south-africa-inflation, [Accessed: 3 June 2013]. 
ArcelorMittal (2006) Annual report: 2006. [Online]. Available at http://www.arcelormittalsa.com/ InvestorRelations/2006/annual/ARPDF/fullreport.pdf, [Accessed: 11 April 2013].

ArcelorMittal (2008) Annual Report: 2008. Johannesburg: ArcelorMittal.

ArcelorMittal (2010) Annual Report: 2010. [Online]. Available at http://www.arcelormittalsa. com/Portals/0/ArcelorMittal_full_Lo-res2.pdf, [Accessed: 1 February 2013].

ArcelorMittal (2011) Annual Report: 2011. Johannesburg: ArcelorMittal.

Bacon N. Blyton P. and Morris J. (1996) 'Among the Ashes: Trade Union Strategies in the UK and German Steel Industries', British Journal of Industrial Relations. 4 (1):25-50.

Bamber, G. (1988) 'Technological change and trade unions'. in: R. Hyman, and W. Streeck, (eds.) New technology and Industrial Relations. Oxford: Basil Blackwell, pp. 204-219.

Buhlungu S. (2010) A Paradox of Victory: COSATU and the Democratic Transformation in South Africa. Scottsville: University of Kwa Zulu Natal Press.

Competition Tribunal (2004) 'In the large merger between LNM Holdings N V and Iscor Ltd', Case no.: 08/LM/Feb04', Johannesburg, [Online]. Available at http:www.saflii.org/za/cases/ ZACT/2004/41.rtf, [Accessed: 8 April 2013].

Conradie, J. (2006) 'Mittal Steel South Africa Limited (previously known as Iscor South Africa Limited) Appellant and Mondli Shadrack Hlatshwayo Respondent'. Case number: 326/05, The Supreme Court of Appeal, Bloemfontein.

COSATU (2012) Secretariat Political Report of the 11th National Congress. Johannesburg: COSATU.

Croock, S. (2013) 'Data collection, analysis and interpretation in respect of Iscor and ArcelorMittal Limited, 1989 - 2012'. Report prepared for Mondli Hlatshwayo, December 2013.

Diamond D. (2010) 'Solidarity: South Africa's majority white union adapts to the post-apartheid world'. Institute for Research on Labor and Employment's Strategic Decision-Making in Labor and Social Movement Organizations Conference. [Online]. Available at http://papers.ssrn.com/ sol3/papers.cfm?abstract_id=1980341, [Accessed: 3 March 2013].

Faku, N. (2013) 'ArcelorMittal issues majeure after fire: Vanderbijlpark operations closed down'. Business Report, 2 February 2013, [Online]. Available at http://www.arcelormittalsa.com/ Portals/0/ArcelorMittal\%20SA\%20issues\%20force\%20majeure\%20after\%20fire.pdf, [Accessed: 2 January 2014]. 
Forrest K. (2005) Power, independence and worker democracy in the development of the National Union of Metalworkers (NUMSA) and its Predecessors 1980-1995. Unpublished Doctoral Thesis. University of the Witwatersrand, Johannesburg.

Forrest, K. (2009) 'Win-win: German union engages the bosses'. South African Labour Bulletin $33(2): 52-55$.

Forrest, K. (2011) Metal that will not bend: National Union Metalworkers of South Africa 1980 1995. Johannesburg: Wits University Press.

Freire, P. (1993) Pedagogy of the oppressed. New York: Continuum.

Ghosh P., Nandan, S. and Gupta A. (2009) 'The changing roles of trade unions in India: A case study of National Thermal Power Corporation (NTPC)'. Asian Academy of Management Journal 14(1): 37-57, [Online]. Available at http://web.usm.my/aamj/14.1.2009/AAMJ\% 2014-1-3.pdf, [Accessed: 12 September 2012].

Hlatshwayo M. (2003) 'The politics of production and forms of worker response at the Iscor Vanderbijlpark Works, 1965-1973', Master of Arts, Research Report. University of the Witwatersrand, Johannesburg.

Hlatshwayo, M. (2010) 'Notes on Factory Visit', Date of the visit: 24 June 2010', ArcelorMittal Vanderbijlpark Plant.

Hlatshwayo, M. (2012a) Trade union responses to technological changes and production: Towards a proactive approach to production. Paper presented at the NUMSA/IG Metall/Fredich Ebert Stiftung Automotive Conference, Johannesburg, October 2012.

Hlatshwayo, M. (2012b) Report of the Solidarity meeting held on 25th of January 2011. Vanderbijlpark.

Iscor (1991) Annual Report 1991. Pretoria: Iscor.

Iscor (1992) Annual Report 1992. Pretoria: Iscor.

Iscor (2003) Annual Report 2003. Pretoria: Iscor.

Iscor Vanderbijlpark (1993) Vanderbijlpark Project. Vanderbijlpark: Iscor.

Iscor Vanderbijlpark (1983) 'Omega'. Historical Papers. NUMSA Archive AH2555, ci. 1987-1990. University of the Witwatersrand.

Jarvis D., Isaacs S., Nicholson J. and Phillips, G. (1999) Making sense of workplace restructuring. Durban: Trade Union Research Project. 
Johnston R. (2010) 'ArcelorMittal fatality rate unacceptably high: Zero fatalities remain top priority for joint global health and safety committee', International Metalworkers Federation, 1 February 2010, [Online]. Available at http://www.imfmetal.org/index.cfm?c=21982, [Accessed: 3 August 2012].

Lourens, C. (2004) 'Solidarity May Strike Against Iscor Job Cuts'. All Africa.com, 13 June 2004, [Online]. Available at http://allafrica.com/stories/200401130264.html, [Accessed: 6 March 2013].

Lukman, S. (2007) 'The Nigeria labour congress and the challenges ahead'. 16 February 2007, [Online]. Available at http://www.gamji.com/article6000/NEWS6826.htm, [Accessed 15 October 2012].

Mantashe G. (2008) 'The decline of the mining industry and the response of the mining unions'. Research Report. Master of Arts. University of the Witwatersrand, Johannesburg.

Maree J. (1984) 'Trade unions, redundancies and new technology agreements'. School of Economics, University of Cape Town: Southern Africa Labour and Development Research Unit (SALDRU).

Maree J. and Godfrey S. (2005) 'If you can't measure it, you can't manage it': Reorganization of work and performance at two fish processing firms', Beyond the apartheid workplace: Studies in transition. Scottsville: University of KwaZulu Natal Press, pp. 125-148.

Mashilo A. (2010) 'Changes in work and production organisation in the automotive industry value chain: An evaluation of the responses by labour in South Africa'. Research Report. Master of Arts. University of the Witwatersrand, Johannesburg.

Masondo D. (2005) 'Trade liberalisation and work restructuring in post-apartheid South Africa' in E. Webster and K. von Holdt (eds.) Beyond the apartheid workplace: Studies in transition. Scottsville: University of KwaZulu Natal Press, pp. 149-172.

Masondo T. (2012). 'The sociology of upward social mobility among COSATU shop stewards' in S. Buhlungu, and M. Tshoaedi (eds.) COSATU's Contested Legacy South African trade unions in the second decade of democracy. Cape Town: Human Science Research Council, pp. 149172.

Masondo, T. (2010) Worker Participation in Workplace Restructuring in the Automotive Industry: A Comparative Study of German and South African Volkswagen Plants 19702009. Research Report. Master of Arts. University of the Witwatersrand, Johannesburg.

Mathews, J. (1989) Tools of change: New technology and the democratisation of work. Sydney: Pluto Press. 
Mathews, J. (1994) Catching the wave: Workplace reform in Australia (No. 26). Ithica: Cornell University Press.

MEIBC (2013) 'MEIBC Background and context'. [Online]. Available at http://www.meibc.co.za/ index.php?option=com_k2\&view=item\&layout=item\&id=134\&Itemid=28, [Accessed 11 December 2013].

Mthiyane T. (2008) 'Industry wage agreement vs Rising CPIX'. From NUMSA Head Office. [letter] To SEIFSA and other Employers' Organisations. Letter dated 25 March 2008. (Document in author's possession).

Neuman, W.L., 2010. Social research methods: Quantitative and qualitative methods. London and Boston: Allyn.

NUMSA. (2012) 'Secretariat Report: Organisational Matters'. 9th National Congress held in Durban. Durban: NUMSA.

Phillips G. (2000) 'New technology higher skills and fewer jobs'. South African Labour Bulletin, 24(1), pp. 42-44.

Rosenthal, T. (2000a) The Steel in South Africa in the 21st Century: A Case Study of Iscor. Geneva: Sociology of Work Unit at the University of Witwatersrand and the International Labour Organisation (ILO), pp. 1-9.

Rosenthal, T. (2000b) The Steel in South Africa in the 21st Century: A Case Study of Iscor. Geneva: Sociology of Work Unit at the University of Witwatersrand and the International Labour Organisation (ILO), pp. 1-7.

Saiyadain, M.S. (2001) 'Modernization of mind at Tata Steel', Indian Journal of Industrial Relations. 36(3): 363-375.

Sandberg A. (1985) 'Socio-technical design, trade union strategies and action research. Swedish centre for Working Life' [Online]. Available at http://ifipwg82.org/sites/ifipwg82.org/files/ Sandberg.pdf, [Accessed: 12 May 2012].

Sikwebu, D. (2003). Pressing challenges facing the South African labour movement: an interview with John Appolis and Dinga Sikwebu. Rethinking the Labour Movement in the 'New South Africa', London: Ashgate, pp. 205-225.

Sitas, A. (1983) 'African worker responses on the East Rand to changes in the metal industry'. Unpublished Doctoral Thesis. University of the Witwatersrand, Johannesburg.

Solidarity, 2006. Solidarity and CWU announce biggest Telkom campaign ever. Pretoria: Solidarity. [Online]. Available at http://www.solidaritysa.co.za/Home/wmview.php? ArtID=345, [Accessed: 18 January 2012]. 
Thelen, K. (1991) Union of parts: Labor politics in post-war Germany. New York: Cornell University Press.

Visser, W.P. (2006) 'From MWU to Solidarity: A Trade Union Reinventing Itself. South African Journal of Labour Relations, 30(2), pp. 19-41.

Von Holdt, K. (1995) 'NUMSA's Three-year Programme: Addressing the Question of Power', South African Labour Bulletin, 19(2):13-23.

Von Holdt, K. (2003) Transition from Below: Forging Trade Unionism and Workplace Change in South Africa. Scottville: University of Natal Press.

Von Holdt, K. and Webster, E. (2005) 'Work Restructuring and the Crisis of Social Reproduction: A Southern Perspective', in E. Webster and K. Von Holdt Beyond the Apartheid Workplace: Studies in Transitions. Scottsville: University of the KwaZulu Natal, pp. 3-40.

Webster, E. (1985) Cast in a racial mould: Labour process and trade unionism in the foundries. Johannesburg: Ravan Press.

Webster, E., Mashilo A., Masondo, T. and Bischoff, C. (2009) 'Changes in the Production Systems and Work Methods, National Union of Metalworkers of South Africa', Johannesburg: Frederick Ebert Foundation, Sociology of Work Programme and Development Institute for Trade Union Support and Education for Labour.

Xaba, J. (2003) 'Employee assistance programme and retrenchment: a South African case study', Research Report. Masters of Arts. University of Johannesburg, Johannesburg.

Zhang. Z. \& Wildemud, B. (2009) 'Qualitative Analysis of Content', [Online]. Available at http://www.ischool.utexas.edu/ -yanz/Content_analysis.pdf, [Accessed: 12 April 2013].

Zikalala, S., 1992. Iscor Violence: Union Splits, Shop Stewards Die. South African Labour Bulletin, 16(8), pp. 126-130.

\section{BIOGRAPHICAL NOTE}

MONDLI HLATSHWAYO is a researcher in the Centre for Education Rights at the University of Johannesburg. His areas of research include trade union responses to production technologies, trade union responses to xenophobia, education, social movements and political economy. 